Open Access

\title{
Retraction Note: Intragastric exposure to titanium dioxide nanoparticles induced nephrotoxicity in mice, assessed by physiological and gene expression modifications
}

Suxin Gui ${ }^{1+}$, Xuezi Sang ${ }^{1+}$, Lei Zheng ${ }^{1}$, Yuguan Ze ${ }^{1+}$, Xiaoyang Zhao ${ }^{1+}$, Lei Sheng ${ }^{1}$, Qingqing Sun ${ }^{1}$, Zhe Cheng ${ }^{1}$, Jie Cheng ${ }^{1}$, Renping Hu${ }^{1}$, Ling Wang ${ }^{1}$, Fashui Hong ${ }^{1}$ and Meng Tang ${ }^{2,3^{*}}$

\section{Retraction Note}

This article [1] has been retracted by the Editor. A committee at Soochow University has investigated this case and supports the decision to retract the article. Incorrect statistical methods were used to calculate mean and S.D. values and additional errors were made in determining 8-OHdG concentrations. The committee also found that some of the original data were missing. We apologize to the readership of Particle and Fibre Toxicology.

\section{Author details}

${ }^{1}$ Medical College of Soochow University, Suzhou 215123, China. ${ }^{2}$ Key Laboratory of Environmental Medicine and Engineering, Ministry of Education, School of Public Health, Southeast University, Nanjing 210009, China. ${ }^{3}$ Jiangsu key Laboratory for Biomaterials and Devices, Southeast University, Nanjing 210009, China.

Received: 23 June 2015 Accepted: 23 June 2015

Published online: 14 July 2015

\section{References}

1. Gui S, Sang X, Zheng L, Ze Y, Zhao X, Sheng L, et al. Intragastric exposure to titanium dioxide nanoparticles induced nephrotoxicity in mice, assessed by physiological and gene expression modifications. Part Fibre Toxicol. 2013;10:4

* Correspondence: tm@seu.edu.cn

${ }^{\dagger}$ Equal contributors

${ }^{2}$ Key Laboratory of Environmental Medicine and Engineering, Ministry of Education, School of Public Health, Southeast University, Nanjing 210009, China

${ }^{3}$ Jiangsu key Laboratory for Biomaterials and Devices, Southeast University, Nanjing 210009, China

Submit your next manuscript to BioMed Central and take full advantage of:

- Convenient online submission

- Thorough peer review

- No space constraints or color figure charges

- Immediate publication on acceptance

- Inclusion in PubMed, CAS, Scopus and Google Scholar

- Research which is freely available for redistribution 